\title{
Missed Opportunities: Human rights and the politics of HIV/AIDS
}

\section{JOANNE CSETE}

\begin{abstract}
There is a strong consensus internationally that human rights violations fuel the AIDS epidemic, but donors and governments of affected countries do little to address a wide range of AIDS-related rights abuses. Joanne Csete argues that political factors, including the rising power of religious fundamentalism, the influence of the US in AIDS assistance programmes, and maledominated political power, create a conducive environment for these abuses and must be addressed in the fight against AIDS.
\end{abstract}

KEYWORDS religious fundamentalism; gender; discrimination; abuse; stigma

\section{Introduction}

HIV/AIDS has broken the mould of infectious disease epidemics in human history. Whereas most other such epidemics have preyed upon young children and very old people - those whose capacity to resist infection is weakest - HIV/AIDS claims the lives of young adults in their prime, and while many of the other very destructive infectious epidemics have spread by air or casual contact, HIV transmission requires an action such as sex or venous injection that often comes with the baggage of cultural taboo and social judgment. Persons who succumb to plague, haemorrhagic fever or tuberculosis are often regarded as 'innocent victims', but this judgement is rarely made of people living with HIV/AIDS. Governments may at times go out of their way to deny the presence of epidemics other than AIDS within their borders - witness China and SARS, for example - but HIV/AIDS set a new standard for official denial as millions of Africans had died of AIDS before most African heads of state had even acknowledged the disease publicly.

Jonathan Mann, the first director of the WHO Global Programme on AIDS (UNAIDS' precursor) beginning in 1987, was the rare expert who understood the special qualities of this epidemic from its earliest days. Observing the emergence of a disease whose main sufferers were gay and bisexual men, sex workers and injection drug users, Mann knew that the fight against HIV/AIDS would have to contend with the social ostracism faced by these persons since long before AIDS' advent. Mann consistently asserted that discrimination and human rights abuse were not only the result of HIV/AIDS but were also causes of it. Discrimination and the marginalization it implies, he said, would drive underground those most in need of AIDS-related services and information (Mann, 1999). 
Awards are given and conferences are held to honour the legacy of Jonathan Mann's ideas. 'Stigma and discrimination' was the theme of the UN's global AIDS campaign in 2002-2003. The World Bank, not generally known for the strong human rights content of its projects, regularly invokes the need to fight AIDS-related discrimination in its AIDS documents and pronouncements (see World Bank, 1999; and statements on World Bank website, www1.worldbank.org/hiv_aids). The Declaration of Commitment from the United Nations General Assembly Special Session on HIV/AIDS calls on all governments to make plans of action to 'confront stigma, silence and denial' and 'eliminate discrimination and marginalization' of people affected by AIDS (UN General Assembly, 2001).

But do these statements amount to much? The human rights abuses anticipated by Mann as causes and consequences of HIV/AIDS still run rampant in the world. This article explores political factors that in many settings have allowed human rights violations to fuel AIDS and thus to impede the fight against this scourge.

\section{The many faces of 'stigma and discrimination'}

Many human rights abuses related to HIV/AIDS have their origin in stigma or discrimination, but these terms seem inadequate to describe the full range of abuses that impedes the fight against HIV/AIDS. For example, there are millions of people for whom the provision of condoms, clean syringes or sound information on prevention of HIV transmission is useless because they are women who face violence when they demand condom use by their sexual partners or they are injection drug users whose access to needle exchange services is blocked by police harassment or social ostracization. Millions of young people cannot realize their right to basic information on HIV and safer sex in part because their governments are influenced or dominated by persons who believe this information encourages immor-

\section{Violence against women}

'Stigma and discrimination' seems inadequate to convey the depth of subordination of and violence against women and girls that are driving forces of HIV/AIDS. It is only relatively recently that this subordination and violence have figured in analyses of the AIDS epidemic (see for example, Royal Tropical Institute, 1998; UNIFEM, 2000). The idea has been slow to dawn that 'ordinary' married women are at very high risk of HIV as men face little or no social disapproval for having sex partners outside marriage, but women face violence and abuse if they demand condom use or refuse sex. Domestic abuse is very rarely understood as a risk factor for HIV (see for example Maman et al., 2002; HRW, 2003e), and programmes to stem domestic violence are not seen as part of national AIDS responses. Women are often constrained to remain in unsafe marriages because inequitable property and divorce laws ensure their economic dependence on their husbands. Widows in Africa (and beyond) who may have been infected with HIV by their husbands often face rejection and appropriation of their homes by their husbands' families (HRW, 2003b).

Repression of women and girls has deep and complex roots. Legal remedies may not be sufficient to address the problem, but they are necessary. In many countries, customary law and practice that disempower women are allowed to trump statutory, often constitutional, nondiscrimination provisions. In some countries where the laws to protect women's rights are quite sound, nonenforcement of the law or abuse of women and girls who make formal complaints to the police may negate the value of legal protection (HRW, 2002c: 68-73; 2003e: 53-61). (See Figure 1).

\section{Child rights}

The horrifying array of human rights abuses faced by children whose parents are dying or have died of AIDS is testament to deep social disdain of AIDS, particularly since children usually inspire some sympathy in the public mind. Children affected by AIDS are frequently denied their right to an education, abandoned or abused by relatives, 


\section{Csete: Human Rights and HIVIAIDS}

forced to live on the streets where they face police harassment and other abuse, obliged to take on hazardous labour (including prostitution), susceptible to being trafficked, highly vulnerable to sexual abuse, and denied their inheritance rights (HRW, 2001, 2003a). Very few countries have appropriate legal and judicial mechanisms for children to defend their property and inheritance rights (HRW, 2001: 19-21). Human Rights Watch has documented numerous shocking cases of sexual abuse of girls orphaned by AIDS, including at the hands of their guardians (for example, HRW, 2002c: 25-31). Many orphans told us that their guardians felt they could demand anything of them since their parents died of AIDS and no one else would be likely to take them in.

\section{Discrimination against drug users and gays}

In the region with the fastest growing AIDS epidemic, Eastern Europe and the Former Soviet Union, the spread of AIDS is fueled by injection drug use. Drug use in much of this region is subject to Draconian laws that violate drug users' human rights and only validate the societal abuse faced by drug users (Neier, 2003a). It seems little recognized at policy levels in the region that the abuse of drug users' rights in society and under the law dramatically undermines the fight against HIV/ AIDS (Malinowska-Sempruch et al., 2003). In Kazakhstan, for example, Human Rights Watch documented abuses of injection drug users, including police harassment, abuse in detention constituting torture, discrimination, and lack of due process in the criminal justice system, all of which contributed to the inability of users to gain access to sterile syringes, a key to containing the country's fast-growing epidemic (HRW, 2003c).

It is not only the former Soviet states in which abuses against drug users have greatly hampered anti-AIDS efforts. In Thailand, a country widely lauded as a 'success story' in its anti-AIDS measures (Agalawatta, 2003), drug users have been lethally dehumanized. In 2003, the Thai government's 'war on drugs' included crackdowns that resulted in the extrajudicial execution of over 2500 alleged drug users and dealers (Neier, 2003b; Dinmore and Kazman, 2003). In China, injection drug users are subjected to atrocious mistreatment through forced labour and social reeducation' in the midst an AIDS epidemic shrouded in secrecy (HRW, 2003f: 42-48). Official demonization of drug users greatly impedes the design and implementation of HIV prevention or AIDS care efforts for this population.

Narcotics drug addiction is the only health disorder dealt with explicitly in international treaties, namely the United Nations drug control treaties of 1961, 1971 and 1988, two of which predate the identification of the human immunodeficiency. ${ }^{1}$ Unfortunately, these treaties regard narcotics addiction as a criminal rather than a public health matter and compromise AIDS programmes by encouraging countries to adopt repressive antidrug strategies and draconian laws (Bewley-Taylor, 2003: 171-173). Stunningly, one of these treaties even classifies methadone as an illicit substance with no therapeutic value (see Annex to Single Convention on Narcotics Drugs, 1961, Schedule I), though methadone and other replacement therapies for heroin users are a central and highly effective element of HIV prevention policy in many countries. ${ }^{2}$ Gay and bisexual men, as well as men who have sex with men (MSM) but who identify themselves as heterosexual, are subjected to human rights abuses that go beyond stigma to vilification and criminalization. A little analysed aspect of HIV/AIDS in Africa, for example, is the public condemnation of gays by heads of state and other political figures, which has galvanized support for criminalization of same-sex behaviour. Ugandan president Yoweli Museveni, who has been praised worldwide for his leadership against AIDS, has reportedly ordered that all homosexuals in Uganda be arrested for 'abominable acts' (Busharizi, 1999). In Egypt, the state has carried out violent crackdowns against gay men since 2001 to combat the threat of 'sexual perverts' to the nation's moral and cultural purity (HRW, forthcoming). In India, section 377 of the Indian Penal Code, which outlaws 'unnatural offences' is used to justify violent police harassment of MSM, including those working as AIDS educators (HRW, 2002a: 19-26). 


\section{Inadequate education}

The inability to realize the right to basic information about HIV/AIDS is widespread (see for example UN Department of Social and Economic Affairs, 2002: vii-x) and results from many factors, some but not all of which are related to violations of human rights. Surveys indicate that girls have poorer access to information on HIV/AIDS than boys in many countries (ibid.: 6-7), perhaps related to discriminatory access to education and health services. In addition, state censorship is a strong factor in this lack of access to information in some countries. In India, which is home to one of the largest emerging AIDS epidemics in the world, the government has done little to redress traditions that keep basic information on sex and sexually transmitted diseases from young people and adults alike (Dube, 2001; Jha, 2002). Only one of India's 35 states had a sex education programme in public schools as of late 2003, though the health ministry said this would change (BBC, 2003).

Nowhere is state censorship of basic information on HIV/AIDS better exemplified than in the United States. In response to President George W. Bush's call for a major initiative to combat HIV/ AIDS abroad, the US Congress in June 2003 passed an act requiring that 33 per cent of the HIV prevention funds of this initiative go to support 'abstinence only until marriage' programmes (Abrams, 2003; US Congress, 2003). There is broad consensus among experts that teaching abstinence should be one tool among many in HIV prevention programmes. The version of abstinence-only 'education' promoted by the Bush administration, however, usually includes the message that condoms are ineffective for HIV prevention (HRW, 2002 b: 23-25). In addition, abstinence-only programmes supported by the US are inherently discriminatory to gay, lesbian, bisexual and transgender persons as they promote the idea that heterosexual marriage is the only legitimate context for sex (HRW, 2002b: 34-39; US House of Representatives, 2003: 4-6).

The human rights abuses described above are linked to increased risk of HIV transmission. More ready living with HIV/AIDS also face a staggering array of human rights abuses, in many cases underwritten by discriminatory laws (see for example Lange, 2003; Aggelton, 2000). In many parts of the world, people with AIDS are denied the right to marry, denied entry to universities in others, quarantined in prison and other institutions, and denied housing and jobs. Because of their HIV status they are refused basic healthcare by health professionals who should know better, and abused by police and other agents of the state. They are denied entry to many countries by restrictive policies that have no foundation in public health. And, of course, despite recent developments such as the 'three by five' initiative of WHO, the vast majority of people with AIDS the world over have little hope for sustainable and affordable treatment to prevent a premature and horrible death.

\section{Politics of HIV/AIDS: Impeding a rights- centred response}

The abuses described above are social evils, but they are also deeply political. On a simple level, the epidemiology of AIDS as a slow-onset disease provides an opportunity for a politics of denial that government leaders seem only too happy to exploit. In a more complex way, the course of the AIDS epidemic has reflected and continues to reflect the politics of racism, globalization, religious fundamentalism and superpower relations.

It is in some ways unsurprising that AIDS was allowed to reach catastrophic proportions in Africa. Sub-Saharan Africa is the region most left behind by post-Cold War politics and globalization. It accounts for about 2 per cent of global trade and has seen the prices of its natural resources plummet in recent decades (Shacinda, 2003). There was little political or economic pressure on the 'international community' to do anything but stand idle as the stranglehold of AIDS on Africa tightened. Donor nations found it easy to be dismissive to a point that some have characterized as racism. As Peter Piot of UNAIDS said of global inaction on AIDS in Africa, "if this [had] happened in the Balkans, or in Eastern Europe, or in Mexico, with white people, the reaction would have been 


\section{Csete: Human Rights and HIVIAIDS}

different' (Gellman, 2000). Gellman reports that the dominant US analysis of Africa's health problems in the early 1990s was that they were caused by overpopulation and that key players in Washington asserted that population decline linked to AIDS mortality in Africa might benefit the continent economically. Attitudes have changed, but only after AIDS established a powerful foothold on the continent.

Religious fundamentalism appears to be on the rise as a political force in many parts of the world. The political power of religious fundamentalism is viewed by some observers as an inevitable backlash against the rapid spread of 'western' ideas in the new global economy. As Altman (2002: 139) notes, in the face of globalized information flows, fundamentalist political leaders are often able to drum up support for even the most draconian social controls, especially in matters such as sex and drugs. The ruling Bharatiya Janata Party (BJP) of India and the Hindu fundamentalist groups under its wing are a case in point. The BJP, which turned up the volume of its Hindu fundamentalist (and anti-Muslim) message in the aftermath of September 11, 2001, has persecuted MSM in the name of upholding 'national values' or Hindu values (HRW, 2002a: 19-20). The political power of religious extremists around the world has not only brought scientifically discredited abstinence approaches to the front of the policy agenda, as noted above. It also tends to shore up sodomy laws, galvanize support for cruelly repressive drug laws, and keep women and girls in subordinate roles. Superpower politics being what it is, the flourishing of religious extremism in the halls of power in Washington bodes ill for HIV/AIDS policies that are based on protection of rights rather than on preaching abstinence.

Politics underpins the subordination of women and girls, particularly in places where women are little seen in political office. It is unsurprising that African governments have generally been unwilling to tackle the hard issues of a double standard for sexual behaviour of women and men that underlie HIV transmission when parliaments and executive branches are so dominated by men. Donor countries could do much more to encourage affected countries to place these problems at the centre of their fight against AIDS.

In the demonization of drug users in the law and in society in many countries, one cannot help but see the heavy influence of the United States' 'war on drugs'. The US continues to criminalize drug addiction rather than treating it as the medical disorder that it is and in the process greatly limits access to syringe exchange programmes, methadone therapy, and other proven HIV prevention measures that are a central part of AIDS policy in much of Europe, Canada and Australia (HRW, 2003d). The UN Commission on Narcotic Drugs (CND) should be a forum for open debate on evolution of policy beyond a criminal law-dominated approach, but CND debates on HIV prevention and other public health measures are stifled by the US and its allies (Fazey, 2003).

\section{Conclusion: What can be done}

The abuses described above are entrenched, numerous and undergirded by strong political forces, but there are many clear and feasible remedies. Governments should be helped to identify basic legal and policy measures that will afford protection to women and children affected by AIDS, especially in the matter of property and inheritance rights and protection from sexual abuse and violence. Civil rights protections and evidence-based HIV prevention services for injecting drug users, including those in prison, should be a high priority. Realization of the right of all persons to basic information about HIV transmission and access to condoms must be central to prevention programmes. But none of these objectives will be realized unless multinational institutions and national political leaders outside the US see their way clear to standing up to Washington.

For good or ill, donors retain enormous influence over AIDS programmes and policies in affected countries. Curbing human rights violations is likely to be an unpopular part of national AIDS programmes and thus an area where donor support may be particularly crucial. That support, as already noted, is unlikely to come from the United States. The Global Fund to Fight AIDS, Tuberculosis and Malaria is an important new 
player in the AIDS donor world, but its project review criteria give short shrift to human rights concerns (Global Fund, 2004). The Global Fund has shown no signs so far of exerting pressure on governments to include human rights protections in their HIV/AIDS efforts. The World Bank has devoted hundreds of millions of dollars to AIDS programmes but not used its leverage to address related human rights issues. For example, there is at this writing a petition before the Delhi High Court to repeal the sodomy law in the Indian Penal Code that, as noted above, undermines the national AIDS programme, which is largely underwritten by the World Bank. The Bank could have a tremendous impact if it spoke out against such laws in India and elsewhere.

The various institutions of the United Nations system, for which human rights is a key founding principle, should do more. As noted above, three UN treaties shore up repressive narcotics control policies. The human rights bodies of the United Nations and the cosponsor organizations of UNAIDS should be up in arms about this, but there is silence from those quarters on the three treaties. United Nations agencies, including the cosponsors of UNAIDS, are virtually inaudible on the essential matter of the rights of gays, lesbians, bisexuals and transgender persons. UNAIDS has only recently formed a committee to look systematically within the UN system at abuses against women linked to HIV/AIDS (Joint U.N. Programme on HIV/AIDS, 2003). The UN agencies through their 'programmes of cooperation' with governments at the national level need to become a voice for the integration of human rights protection and promotion in HIV/AIDS programmes.

Finally, there should be better documentation of the successes against AIDS that have resulted from working respectfully with persons at highest risk and those living with the disease. Syringe ex-

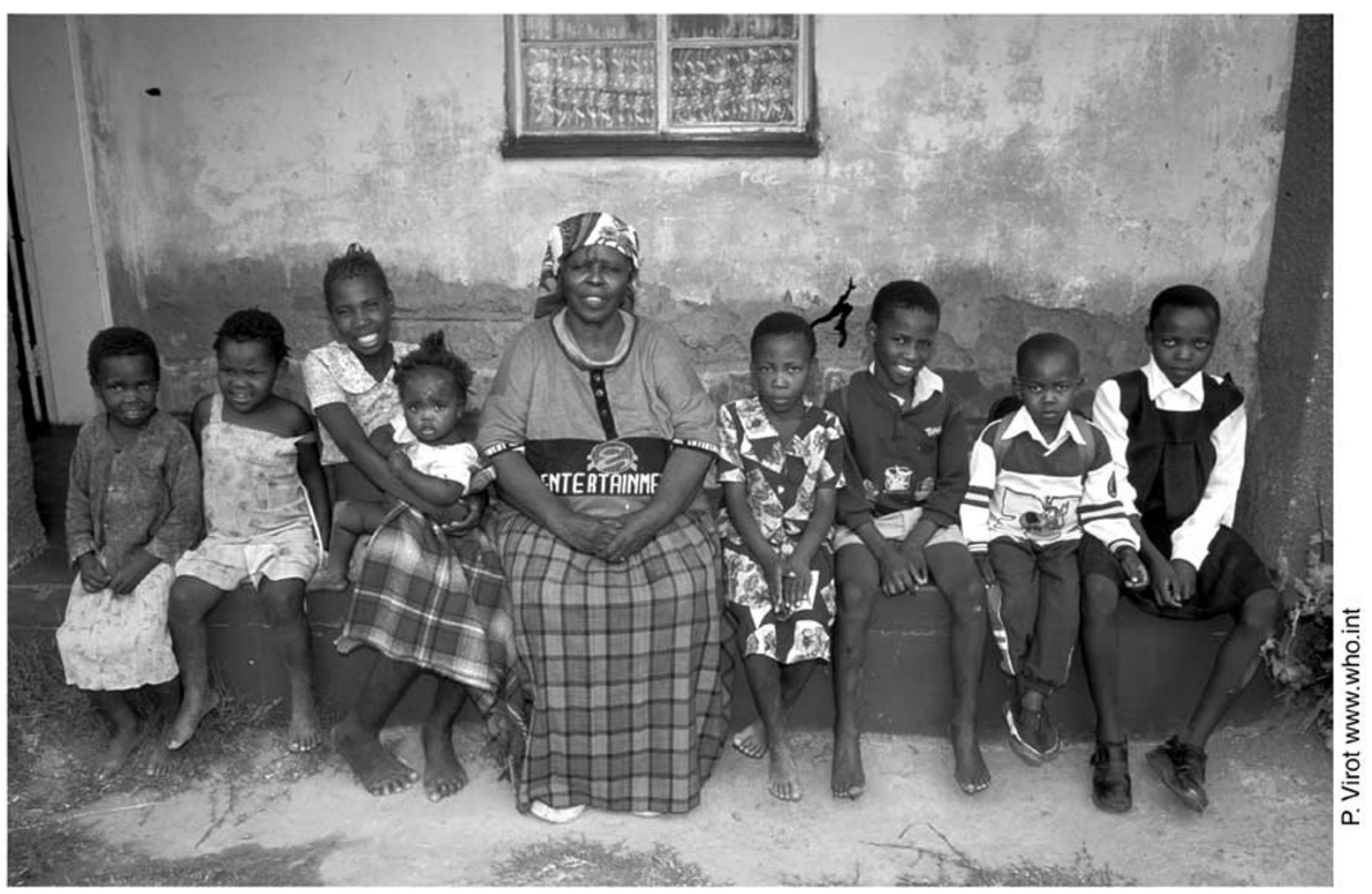

Figure 1: In Lesotho, a foster mother with her HIV/AIDS orphans - one of the most needed community responses to the HIV/AIDS crisis in rural Africa. 


\section{Csete: Human Rights and HIVIAIDS}

change, methadone replacement therapy, supervised injection sites and other measures have greatly reduced new HIV infections among drug users in numerous countries, but these stories have little currency in some parts of the world. As an estimated one-third of new HIV transmission outside Africa is associated with injection drug use, these programmes are urgently needed (Wolfe and Malinowska-Sempruch, forthcoming). There have been stunning successes in HIV prevention among sex workers in South Asia through sex worker collectives (Dugger, 1997; Dube, 2000: 128-129) - and yet the US government denies support to HIV research or services involving sex workers (Goode, 2003; Burkhalter, 2004). The real-life experience of over 20 years of fighting AIDS needs to be better communicated to and understood by politicians to counter inevitable political pressures against evidence-based approaches and in favour of politically expedient repression. The opportunities for real rights-based success against AIDS should not be missed.

\section{Notes}

1 The texts of all three treaties, including schedules, final acts and resolutions, are available on the International Narcotics Control Board website (www.incb.org).

2 Substitution or replacement therapy with methadone or buprenorphine has a long record of success in providing an alternative to injected heroin for drug users and is thus a central strategy for HIV prevention in many countries. Most such replacement therapy programmes enable heroin users to stop injecting because the replacement drug (methadone, for example) is administered orally. Even in the US, where federal and state regulations limit access to methadone and closely regulate methadone programmes, the White House Office on Drug Policy has recognized the importance of oral methadone administration for treatment of heroin addiction and HIV prevention (Executive Office of the President, 2000).

\section{References}

Abrams, J. (2003) 'House Approves Major Global AIDS Bill', Associated Press 1 May.

Agalawatta, U. (2003) 'UN Fetes Thai AIDS Fight But Group Protests Latest Policy', InterPress Service 17 September.

Aggelton, P. (2000) 'Comparative Analysis: Research studies from India and Uganda - HIV and AIDS-related discrimination, stigmatization and denial'. Geneva: UNAIDS.

Altman, D. (2002) Global Sex, Chicago: University of Chicago Press.

Bewley-Taylor, D.R. (2003) 'Challenging the UN Drug Control Conventions: Problems and possibilities', International Journal of Drug Policy 14: 171-9.

British Broadcasting Corporation World Service (2003) 'India Minister Vows to Beat AIDS', 24 November.

Busharizi, P. (1999) 'Ugandan President Orders Arrest of Gays', Reuters 28 September.

Burkhalter, H. (2004) 'The Politics of AIDS: Engaging conservatives activists', Foreign Affairs January/February.

Dinmore, G. and A. Kazmin (2003) 'US Protests to Thailand over Drug War Killings', Financial Times 8 May.

Dube, S. (2000) Sex Lies and AIDS, New Delhi: Harper Collins India.

Dube, S. (2001) 'India's AIDS Explosion', Washington Post 4 January.

Dugger, C. (1997) 'Going Brothel to Brothel, Prostitutes Preach About Using Condoms', New YorkTimes 4 January.

Executive Office of the President, Office of National Drug Control Policy (2000) 'Drug Policy Information Clearinghouse Fact Sheet: Methadone'.Washington, DC: US Government Printing Office.

Fazey, C.S.J. (2003) 'The Commission on Narcotic Drugs and the United Nations International Drug Control Programme: Politics, policies and prospect for change', International Journal of Drug Policy 14: 155-69.

Gellman, B. (2000) 'Death Watch:The global response to AIDS in Africa. World shunned signs of the coming plague', Washington Post 5 July.

Global Fund to Fight AIDS,Tuberculosis and Malaria (2004) 'Guidelines for Proposals: Fourth call for proposals'. Geneva: Global Fund. available at http://www.theglobalfund.org/pdf/2.pp.guidelines_4.en.pdf, accessed 4 January 2004.

Goode, E. (2003) ‘Certain Words Can Trip Up AIDS Grants, Scientists Say', New YorkTimes 18 April.

Human Rights Watch (2001) In the Shadow of Death: HIV/AIDS and children's rights in Kenya, New York: Human Rights Watch.

Human Rights Watch (2002a) Epidemic of Abuse: Police harassment of HIV/AIDS outreach workers in India, New York: Human Rights Watch. 


\section{Development 47(2): Dialogue}

Human Rights Watch (2002b) Ignorance Only: HIV/AIDS, human rights and federally funded abstinence-only programmes in the United States, New York: Human Rights Watch.

Human Rights Watch (2002c) Suffering in Silence: Human rights abuses and HIV transmission among girls in Zambia, New York: Human Rights Watch.

Human Rights Watch (2003a) Borderline Slavery: Child trafficking inTogo, New York: Human Rights Watch.

Human Rights Watch (2003b) Double Standards: Women's property rights violations in Kenya, New York: Human Rights Watch.

Human Rights Watch (2003c) Fanning the Flames: How human rights abuses are fueling the AIDS epidemic in Kazakhstan, New York: Human Rights Watch.

Human Rights Watch (2003d) Injecting Reason: Human rights and HIV prevention for injection drug users. California: A case study, New York: Human Rights Watch.

Human Rights Watch (2003e) Just Die Quietly: Domestic violence and women's vulnerability to HIV in Uganda, New York: Human Rights Watch.

Human Rights Watch (2003f) Locked Doors: The human rights of people living with AIDS in China, New York: Human Rights Watch.

Human Rights Watch Days of Silence, Nights of Fear: Entrapment and torture in Egypt's crackdown on homosexual conduct, New York, forthcoming.

Jha, S. (2002) 'India's Shyness Towards Sexual Education Fuelling AIDS: Activists', Agence France Presse 29 October.

Lange,T. (2003) HIV and Civil Rights: A report from the frontlines of the HIV/AIDS epidemic, New York: American Civil Liberties Union.

Malinowska-Sempruch, K., J. Hoover and A. Alexandrova (2003) Unintended Consequences: Drug policies fuel the HIV epidemic in Russia and Ukraine, New York: Open Society Institute.

Maman, Su, J.K. Mbwambo, N.M. Hogan, G.P. Kilonzo, J.C. Campbell, E. Weiss and M.D. Sweat (2002) 'HIV-positive Women Report More Lifetime Partner Violence: Findings from a voluntary counselling and testing clinic in Dar es Salaam, Tanzania', American Journal of Public Health 92(8): 1331-1337.

Mann, J.M. (1999) 'Human Rights and AIDS: The future of the pandemic', in Jonathan M. Mann, Sofia Gruskin, Michael A. Grodin, and George J. Annas (eds.) Health and Human Rights: A reader, New York and London: Routledge.

Neier, A. (2003a) 'Focus on Human Rights', Harm Reduction News 4(1), 1, Spring.

Neier, A. (2003b) 'The Worlds Other Tyrants Still at Work', New YorkTimes 7, April.

Royal Tropical Institute and Southern Africa AIDS Information Dissemination Service (1998) Facing the Challenges of HIV/AIDS/STDs: A gender-based response, Amsterdam: Royal Tropical Institute.

Shacinda, S. (2003) 'Global Trade Rules Carry Deadly Costs for Africa’, Reuters 4 September.

UN Department of Economic and Social Affairs, Population Division (2002) HIV/AIDS Awareness and Behavior UN document ST/ESA/SER.A/20, New York: United Nations.

UN General Assembly (2001) Declaration of Commitment on HIV/AIDS 28th Special SessionUN document A/RES/S-26-2, 2 August, New York: United Nations General Assembly.

UNIFEM (2000) Gender, HIV and Human Rights: A training manual, New York: UNIFEM.

UN Joint Programme on HIV/AIDS (2003) Global Initiative on Women and AIDS (unpublished memorandum), Geneva: UNAIDS.

United States Congress (2003) HR 1298 (108th Congress), United States Leadership Against HIV/AIDS, Tuberculosis, and Malaria Act of 2003, Washington, DC: US Government Printing Office.

United States House of Representatives, Committee on Government Reform: Minority Staff, Special Investigations Division (2003) Politics and Science in the Bush Administration, Washington, DC: Government Printing Office.

Wolfe, D. and K. Malinowska-Sempruch (2004) Illicit Drug Policy and the Global HIV Epidemic: Effects of UN and national government approaches (Working Paper Commissioned by the HIV/AIDS Task Force of the Millenium Project). New York: Open Society Institute.

World Bank (1999) 'Project Appraisal Document on a Proposed Credit in the Amount of SDR 140.82 Million to India for a Second National HIVAIDS Control Project', Report No. 18918-IN, 13 May. 